\title{
THE ROLE OF FAULT IN CONTRACT LAW: UNCONSCIONABILITY, UNEXPECTED CIRCUMSTANCES, INTERPRETATION, MISTAKE, AND NONPERFORMANCE
}

\author{
Melvin Aron Eisenberg*
}

It is often asserted that contract law is based on strict liability, not fault. This assertion is incorrect. Fault is a basic building block of contract law, and pervades the field. Some areas of contract law, such as unconscionability, are largely fault based. Other areas, such as interpretation, include sectors that are fault based in significant part. Still other areas, such as liability for nonperformance, superficially appear to rest on strict liability, but actually rest in significant part on the fault of breaking a promise without sufficient excuse. Contract law discriminates between two types of fault: the violation of strong moral norms, such as the prohibition of deception, and the violation of somewhat weaker moral norms, such as the requirement of due care. In some areas of contract law, one type of fault dominates. Where both types of fault are relevant, one party's violation of a strong moral norm will normally override the other party's violation of a weaker moral norm. Fault is pervasive in contract law because it should be. One part of the human condition is that we hold both policy and moral values; law cannot escape this condition. Moreover, if moral obligation and fault were removed from contract law, the contracting system would be much less efficient. The efficiency of the contracting system rests on a tripod whose legs are legal remedies, reputational effects, and the internalization of social norms-in particular, the moral norm of promise keeping. All three legs are necessary to ensure the reliability, and therefore the efficiency, of the contracting system.

\section{INTRODUCTION}

The Second Restatement of Contracts states: "Contract liability is strict liability. It is an accepted maxim that pacta sunt servanda, contracts are to be kept. The obligor is therefore liable in damages for breach of contract even if he is without fault ...." Similarly, Farnsworth's treatise states that "contract law is, in its essential design, a law of strict liability, and the

* Koret Professor of Law, UC Berkeley School of Law (Boalt Hall); Stephen and Barbara Friedman Visiting Professor of Law, Columbia Law School.

1. Restatement (SeCOND) of Contracts ch. 11, introductory note (1981). 
accompanying system of remedies operates without regard to fault."2 These statements, and many others like them, are incorrect.

As a normative matter, fault should be a building block of contract law. One part of the human condition is that we hold many moral values concerning right and wrong. Contract law cannot escape this condition. Accordingly, the basic principle that tells us how to make the best possible rules of contract law-or any law, for that matter-must accommodate not only policy and empirical propositions, but also moral values, including values concerning various types of fault. This principle is as follows:

First. If, but only if, appropriate conditions are satisfied, and subject to appropriate constraints, the law should effectuate the objectives of parties to promissory transactions.

Second. The rules that determine the conditions to, and the constraints on, the legal effectuation of the objectives of parties to promissory transactions, and the way in which those objectives are to be ascertained, should consist of those rules that best take into account all relevant moral, policy, and empirical propositions.

Based on this principle, it should not be surprising that fault is a pervasive element in contract law. Some areas of contract law, such as unconscionability, are almost entirely fault based. Other areas, including interpretation, include sectors that are fault based in significant part. Still other areas, such as liability for nonperformance, might superficially appear to be based on strict liability, but can best be understood as resting in significant part on fault.

In this Article, I will discuss some important areas of contract law in which fault should and does figure very heavily. The point is not to exhaust the areas in which fault should and does play an important role, but to illustrate how contract law is fault based to a significant extent, and to examine the different ways in which fault figures in contract law.

Fault comes in different flavors and degrees. For contract-law purposes, fault can be divided into the violation of strong moral norms, such as the norm against lying, and the violation of somewhat weaker moral norms-in particular, the norm that an actor should give due regard to the legitimate interests of others. The major type of contract-law fault in the latter category is negligence, or lack of due care. In this Article I will discuss the role of different kinds of fault in five important areas of contract law: unconscionability, unexpected circumstances, interpretation, mistake, and liability for nonperformance.

2. 3 E. Allan Farnsworth, Farnsworth on Contracts $\S 12.8$, at $195-96$ (3d ed. 2004). 


\section{UNCONSCIONABILITY}

One of the most important developments in modern contract law is the emergence of the principle that an unconscionable contract or term is unenforceable. ${ }^{3}$ Traces of that principle can be found in some older cases, ${ }^{4}$ and equity courts have long reviewed contracts for fairness when equitable relief was sought, ${ }^{5}$ but unconscionability was not a recognized principle under classical contract law. The position of contract law changed radically beginning in the 1960s, following the lead of section 2-302 of the Uniform Commercial Code, which provides that if any contract or contract clause is unconscionable, a court may refuse to enforce the contract or clause or limit the application of the clause to avoid an unconscionable result. Section 2302 was adopted by almost every state, and the principle it embodies has been embraced in other uniform acts, ${ }^{6}$ the Second Restatement of Contracts, ${ }^{7}$ the Second Restatement of Property, ${ }^{8}$ and the case law. However, the meaning and reach of the unconscionability principle is still not fully established.

Early on, an effort was made to reconcile the unconscionability principle with the bargain principle-the principle of classical contract law that bargains are enforceable according to their terms, without regard to fairness. ${ }^{10} \mathrm{~A}$ major step in this direction was a distinction, drawn by Arthur Leff and later adopted by many courts and commentators, between procedural and substantive unconscionability." Essentially, Leff defined procedural unconscionability as fault or unfairness in the bargaining process, and substantive unconscionability as fault or unfairness in the bargaining outcome, even if unaccompanied by unfairness of process. ${ }^{12}$

Procedural unconscionability is easy to reconcile with the bargain principle. That principle rests in significant part on the predicate that private actors are the best judges of their own utility. This predicate, however, only justifies the application of the bargain principle where both parties act

3. For convenience, hereinafter I will use the term "contract" to include contract terms.

4. See, e.g., Campbell Soup Co. v. Wentz, 172 F.2d 80 (3d Cir. 1948); McClure v. Raben, 33 N.E. 275 (Ind. 1893); Richey v. Richey, 179 N.W. 830 (Iowa 1920); Balt. Humane Impartial Soc'y v. Pierce, 60 A. 277 (Md. 1905); Mersereau v. Simon, 8 N.Y.S.2d 534 (N.Y. App. Div. 1938).

5. See, e.g., Loeb v. Wilson, 61 Cal. Rptr. 377 (Ct. App. 1967); Schlegel v. Moorhead, 553 P.2d 1009 (Mont. 1976); McKinnon v. Benedict, 157 N.W.2d 665 (Wis. 1968).

6. See Unif. Consumer Credit Code $\$ 5.108$ (1974); Unif. Residential Landlord and Tenant Act § 1.303(a)(1) (1974); Unif. Consumer Sales Practices Act $\$ 4$ (1971).

7. Restatement (SeCoNd) of Contracts \$ 208 (1981).

8. Restatement (Second) of Prop.: Landlord \& Tenant $§ 5.6$ (1977).

9. See, e.g., Williams v. Walker-Thomas Furniture Co., 350 F.2d 445, 449 (D.C. Cir. 1965) (relying in part on analogy to the 1962 version of $\S 2-302$ ). (1982).

10. See Melvin Aron Eisenberg, The Bargain Principle and Its Limits, 95 Harv. L. Rev. 741

11. Arthur Allen Leff, Unconscionability and the Code-Emperor's New Clause, $115 \mathrm{U}$. PA. L. REV. 485, 487 (1967).

12. Id. 
voluntarily and are fully informed and the bargaining process is fair. Where the bargaining process is unconscionable-unfair-a major predicate of the bargain principle is not satisfied, and that principle therefore cannot properly be applied to enforce the contract.

In contrast, it may seem difficult to reconcile the bargain principle with a regime that allows judicial review of contracts for pure substantive unconscionability, because under such a regime a contract could be found unconscionable even if the bargaining process was fair. Accordingly, the effect, if not the purpose, of the distinction between procedural and substantive unconscionability was to suggest that purely substantive unconscionability should be insufficient to render a contract unconscionable.

The distinction between procedural and substantive unconscionability is useful, but it takes us only so far, and in some ways clouds the relevant issues. Often the distinction will be artificial, because unfairness in the bargaining process will be significant only if the resulting bargain is unfair. Conversely, under some circumstances extracting an unfair contract will be unfair in itself. Finally, the distinction does not address the crucial question, how should it be determined whether a contract is procedurally or substantively unconscionable?

The answer is that with the possible exception of pure substantive unconscionability, two elements-a predicate and a principle-should figure in a determination of unconscionability. The predicate is the nature of the market on which the contract was made. Contracts made on competitive markets will rarely be unconscionable. However, when contracts are made off-market or on markets that are not competitive, the stage is set for unconscionability. The principle is that unconscionability normally turns on whether the contract involved moral fault on the part of the promisee. Regardless of the nature of the market on which a contract is made, a contract will not be unconscionable without the element of moral fault.

\section{A. Markets}

In this Article, I will use the term "competitive market" to mean a market that is either perfectly or reasonably competitive. A perfectly competitive market has four characteristics: a homogeneous commodity; perfect, cost-free, and readily available information; productive resources that are sufficiently mobile that pricing decisions readily influence their allocation; and participants whose market share is so small that none can affect the terms on which the commodity is sold, so that each participant takes those terms as given. ${ }^{13}$ A reasonably competitive market is a market whose characteristics approximate those of a perfectly competitive market. There are relatively few perfectly competitive markets, but many reasonably competitive markets.

13. See, e.g., Edwin G. Dolan, Basic Microeconomics 160 (1983). For ease of exposition, I will use the term "price" to include all the terms offered by a seller. 
Now assume a perfectly competitive market, and let the parties to a bargain be $S$, a plaintiff-seller, and $B$, a defendant-buyer. Given the conditions of a perfect market, the contract price will be the market price. This price will rarely if ever be unconscionable, since in our society a perfectly competitive market is generally regarded as a fair mechanism to set prices because: (1) By normal measures of value, the contract price will be equal to the benefit $S$ has agreed to confer upon $B$. (2) $S$ would not voluntarily have agreed to transfer the commodity to $B$ at any lower price, because if $B$ had not agreed to pay the market price, $S$ could have sold it to another buyer at that price. (3) Since cost-free information is readily available on such markets, the parties to the transaction will almost always be fully informed. (4) The contract price will normally equal the seller's marginal cost plus a normal profit.

The price in a perfectly competitive market will also normally be efficient. First, given that pricing decisions on such a market readily influence the allocation of productive resources, a prospect of above-normal profits will provide an incentive to increase supply, leading to an increase in capacity and a new and lower equilibrium price that yields only normal profits. In contrast, to the extent the price is kept from rising to the equilibrium or market price, there is an incentive to decrease capacity by reallocating resources to other uses and not replacing depleted capital stock. Second, if perfect competition prevails, demand for the commodity would exceed the supply at any price less than the market price. Some mechanism other than price would therefore be required for rationing the supply among competing buyers, and the supply would not be allocated to its highest-valued uses as measured by the amounts competing buyers are willing to pay-assuming, at least, that income is either distributed optimally or can best be redistributed by techniques other than price, such as taxation and subsidy.

These effects are scaled down where a market is only reasonably competitive. For example, because commodities sold on a reasonably competitive market normally will not be homogeneous and information is not cost free, exploitation is a possibility. In general, however, transactions on reasonably competitive markets are unlikely to be unconscionable, for many of the same reasons that transactions on a perfectly competitive market will rarely if ever be unconscionable.

In this connection, however, it is important to distinguish between commodities and the markets on which they trade. In the case of commodities that are sold on competitive markets, contracts are normally made on physical or virtual markets in which the public can readily participate. However, a commodity that is normally sold on a public market may occasionally be sold privately, that is, away from any public market that is readily available to both parties. Where that occurs, the contract should be treated as having been made off-market, even though the commodity may also be traded on a competitive market. Unconscionability is most likely to be found where a transaction occurs either off-market or on a public market that is not competitive. 


\section{B. Moral Fault}

In short, contracts made on perfectly competitive markets will rarely if ever be unconscionable, and contracts made on reasonably competitive markets will not often be unconscionable. However, the converse is not true: a contract that is made off-market or on a noncompetitive market is not unconscionable for that reason alone. Instead, such a contract will be unconscionable only if it involves moral fault on the part of the promisee. Moral fault, for contract-law purposes, should normally mean social morality-moral standards that are rooted in aspirations for the community as a whole and that, on the basis of an appropriate methodology, can fairly be said to have substantial support in the community, can be derived from norms that have such support, or appear as if they would have such support.

The importance of moral fault in this connection is made explicit in many civil-code and civil-code-based rules that operate like the unconscionability principle. For example, the German Civil Code provides:

[A] legal transaction is void by which a person, by exploiting the predicament, inexperience, lack of sound judgment or considerable weakness of will of another, causes himself or a third party, in exchange for an act of performance, to be promised or granted pecuniary advantages which are clearly disproportionate to the performance. ${ }^{14}$

Similarly, the Principles of European Contract Law provide:

(1) A party may avoid a contract if, at the time of the conclusion of the contract:

(a) it was ... in economic distress or had urgent needs, was improvident, ignorant, inexperienced or lacking in bargaining skill, and

(b) the other party knew or ought to have known of this and, given the circumstances and purpose of the contract, took advantage of the first party's situation in a way which was grossly unfair or took an excessive benefit. $^{15}$

Although the essential role of moral fault is not as explicit under American law as it is under some civil-code and civil-code-based rules, it is implicit in the concept of unconscionability: what kind of conduct is not conscionable must depend on what kind of conduct involves moral fault. This is not to say that a contract that involves any moral fault at all is necessarily unconscionable. So, for example, depending on the circumstances, a seller's use of mildly manipulative talk, while unfair, might not be unconscionable. Moral fault comes in different degrees, and the term unconscionable suggests a significant degree of moral fault.

14. Bürgerliches Gesetzbuch [BGB] [Civil Code] Aug. 18, 1896, as amended, $\S 138(2)$ (F.R.G.) (emphasis added), translation available at http://www.gesetze-im-internet.de/ englisch_bgb/index.html; accord Schweizerisches Obligationenrecht [OR] [Code of Obligations] Mar. 30, 1911, as amended, art. 21(1) (Switz.).

15. Principles of European Contract Law art. 4:109(1) (1998) (emphasis added); accord UNIDROIT Principles of Int'l Commercial Contracts art. 3.10(1) (2004). 


\section{UNEXPECTED CiRCUMSTANCES}

I now turn to the area of unexpected circumstances, in which the most salient type of fault is lack of due care. A basic rule in this area is that relief will not be granted where the adversely affected party is at fault for having caused the relevant event. For example, the Second Restatement provides:

Where, after a contract is made, a party's performance is made impracticable without his fault by the occurrence of an event the non-occurrence of which was a basic assumption on which the contract was made, his duty to render that performance is discharged, unless the language or the circumstances indicate the contrary. ${ }^{16}$

Under this rule, fault operates in a binary fashion, like an on/off switch, to bar the adversely affected party from employing an unexpectedcircumstances excuse that she would otherwise be entitled to invoke. However, there is another way to view this problem; fault might instead operate on a continuum, like a dimmer switch. A promisor's fault in causing the unexpected circumstance may be slight or severe. At one extreme, the promisor's fault may consist of reckless conduct or gross negligence. At the other extreme, the promisor's fault may consist only of minor negligence. The location of the promisor's conduct on the fault continuum should affect the promisee's remedy. Where a promisor would be excused by reason of unexpected circumstances but for her fault and her fault is minor, a reasonable accommodation is to require the promisor to pay reliance damagesthe costs that the promisee incurred in reliance on the promise-but not expectation damages. The promisor should be required to pay reliance damages, because she is at fault and her fault has caused the promisee to be worse off than he was before the promise was made. However, the promisor should be excused from paying expectation damages, because but for her fault she would be excused from liability; the fault is minor; and the promisee will have no loss in the usual sense of that term-that is, no diminution in his precontract wealth-after he is compensated for his costs by reliance damages. Accordingly, section 261 of the Second Restatement (quoted above) is complemented by section 272(2): "[i]n any case governed by the rules stated in this Chapter [on impracticability and frustration], if those rules ... will not avoid injustice, the court may grant relief on such terms as justice requires including protection of the parties' reliance interests." 17

A series of four important decisions by the Massachusetts Supreme Court exemplifies this remedial approach. The decisions all arose out of a contract between John Bowen Company, a general contractor, and the Massachusetts Department of Health, acting with the approval of the State Public Building Commission. The contract provided for the construction of

16. Restatement (Second) of Contracts $§ 261$ (1981) (emphasis added); see also id. $\S 266(1)$ (existing impracticability); id. $\S 265$ (discharge by supervening frustration).

17. Id. $\$ 272(2)$. 
the Lemuel Shattuck Hospital in Boston. ${ }^{18}$ The series began with Gifford $\nu$. Commissioner of Public Health, ${ }^{19}$ which concerned the validity of the contract. This case did not involve unexpected circumstances, but it set the stage for the other three decisions. Under a Massachusetts statute, contracts like the one at issue had to be put out to bid and awarded to the lowest qualified bidder. The contract was awarded to Bowen, but another bidder, Slotnik, challenged the award. The Massachusetts Supreme Court held that in setting out the components of its bid, Bowen had failed to fully comply with the statute, and that if Bowen had fully complied, Slotnik would have been the lowest qualified bidder. Accordingly, the court cancelled the award of the contract to Bowen. The next three decisions in the series involved suits against Bowen by subcontractors who had entered into contracts with Bowen before Bowen's contract with the Department of Health was cancelled in Gifford.

The first of these decisions, M. Ahern Co. v. John Bowen Co. ${ }^{20}$ was an action by a plumbing subcontractor, Ahern, for unpaid labor and materials furnished on the hospital project before Bowen's contract was cancelled. The court began by pointing out that although Bowen was not liable for Ahern's expectation damages by reason of the cancellation of Bowen's contract with the Department of Health, that was not the end of the case. The courts, it said, have not been deterred "from giving recovery in cases of excusable impossibility for such performance as has been received." ${ }^{21}$ This was nothing new; it is hornbook law that even where unexpected circumstances excuse expectation damages, they do not excuse restitution for the value of a benefit conferred. ${ }^{22}$ However, the court rejected unjust-enrichment theory as the basis of recovery for what was furnished in suits like that brought by Ahern. The court further held that "[i]t is no longer necessary to find implications of a contract to support recovery." ${ }^{23}$ Instead, the court said, recovery was to be based on "what the court holds to be fair and just in the unanticipated circumstances. ${ }^{24}$ In Ahern itself, the court concluded that what was fair and just turned at least in part on the role Bowen's fault had played in making the contract with Ahern impossible to perform:

This is not a case where the defendant stands fully apart, as the plaintiff does, from the circumstances which caused the unexpected destruction of the subject matter of the contract. The defendant did those things with respect to the subbids discussed in Gifford v. Commissioner of Public Health which caused its bid to appear the lowest, although in fact it was not. The

18. The hospital is alternatively named in the four decisions as "a chronic diseases hospital in Boston" and the "Chronic Disease Hospital and Nurses' Home."

19. 105 N.E.2d 476 (Mass. 1952).

20. 133 N.E.2d 484 (Mass. 1956).

21. Id. at 485 .

22. See, e.g., Restatement (SECOND) OF Contracts § 377.

23. Ahem, 133 N.E.2d at 486.

24. Id. (emphasis added). 
Gifford decision has held that what the defendant did was not properly done. Even though we assume, as the defendant urges here, that it acted in good faith, and in respects as to which the prescribed course was not clear, the fact is that its actions, in a field where it had a choice, had a significant part in bringing about the subsequent critical events-the awarding to it of an apparent contract which turned out to be void and the ensuing decision of this court. In the circumstances it is plain that this is not a case of fully excusable impossibility. ${ }^{25}$

The next decision in the Lemuel Shattuck Hospital series was Boston Plate \& Window Glass Co. v. John Bowen $\mathrm{Co}^{26}$ In this case, Boston Plate, a subcontractor, had entered into subcontracts with Bowen to furnish glass, glazing, and miscellaneous nonferrous metalwork for the hospital. ${ }^{27}$ Subsequently, Bowen notified Boston Plate that it could not proceed with the subcontracts. At that time, Boston Plate had not actually begun its work, but it had made preparations to do so and had incurred expenses in connection with those preparations. However, Boston Plate sued Bowen only for expectation damages for breach of the subcontracts, not for reliance damages based on its preparatory work. Bowen argued that it was not liable on the subcontracts, because the decision in Gifford rendered performance of the contracts impossible. The court agreed.

To summarize the story so far: the occurrence of an unexpected circumstance may excuse the promisor from liability for expectation damages, even where the promisor bears some fault for the occurrence. However, the promisor will not be excused from liability for what the promisee furnished under the contract before the occurrence of the unexpected circumstance. The concept of "furnished," for this purpose, is elastic and depends, in whole or in part, on what is fair and just under the circumstances.

This story leaves open the treatment of costs that a promisee has incurred in cases where the promisee had not furnished anything before the occurrence of the unexpected circumstance. That issue was the subject of the last decision in the Lemuel Shattuck Hospital series, Albre Marble \& Tile Co. v. John Bowen $\mathrm{Co}^{28}$ Albre, another subcontractor, had contracts with Bowen for the installation of marble and tile for the hospital. ${ }^{29}$ Bowen refused to perform its contracts with Albre on the ground that performance had been made impossible by the Health Department's cancellation of its contract with Bowen, and Albre sued Bowen in four counts.

The first and second counts sought expectation damages for Bowen's breach of Albre's contracts. Bowen pleaded impossibility, and the court dismissed these two counts on summary judgment. ${ }^{30}$

25. Id.

26. 141 N.E.2d 715 (Mass. 1957).

27. Id. at 716 .

28. 155 N.E.2d 437 (Mass. 1959).

29. Id. at 439 .

30. Id. 
Albre's third and fourth counts sought to recover the value of its work and labor under its contracts, which consisted of the " 'preparation of samples, shop drawings, tests and affidavits" "rather than labor or materials furnished in the construction of the hospital. ${ }^{31}$ To put this differently, Albre sought reliance damages in its third and fourth counts. Accordingly, a major issue in the case was whether a promisee could recover reliance damages against a promisor who was excused from paying expectation damages by reason of unexpected circumstances. The court concluded that even though Bowen was not sufficiently at fault to be liable for expectation damages, it was sufficiently at fault to be liable for reliance damages:

Although the matter of denial of reliance expenditures in impossibility situations seems to have been discussed but little in judicial opinions, it has, however, been the subject of critical comment by scholars. In England the recent frustrated contracts legislation provides that the court may grant recovery for expenditures in reliance on the contract or in preparation to perform it where it appears "just to do so having regard to all the circumstances of the case."

... [T] his is not a case of mere impossibility by reason of a supervening act. ... Although the defendant's conduct was not so culpable as to render it liable for breach of contract, nevertheless, it was a contributing factor to a loss sustained by the plaintiff which as between the plaintiff and the defendant the latter ought to bear to the extent herein permitted. ${ }^{32}$

In short, the principle, supported by section 272(2) of the Second Restatement, and exemplified by the Lemuel Shattuck Hospital series, is that where the occurrence of an unexpected circumstance would warrant judicial relief except that the promisor is proven to have been at fault, and the fault was minor, the promisor normally should be relieved from liability for expectation damages, but not reliance damages. Of course, if the promisor's fault is more extreme, she will not be able to set up an unexpected-circumstances defense and therefore normally will be liable for expectation damages.

\section{INTERPRETATION}

In the area of unconscionability, the most salient kind of fault is moral fault. In the area of unexpected circumstances, the most salient kind of fault is lack of due care. In some other areas of contract law, both kinds of fault play a role. The play of different kinds and degrees of fault in a single area is well illustrated by four central principles of interpretation.

Principle I. If contracting parties subjectively attached different meanings to an expression, and the two meanings were not equally reasonable, the more reasonable meaning prevails.

31. Id.

32. Id. at $440-41$ (citations omitted). 
Principle I is adopted in section 201(2)(b) of the Second Restatement:

Where the parties have attached different meanings to a promise or agreement or a term thereof, it is interpreted in accordance with the meaning attached by one of them if at the time the agreement was made ... that party had no reason to know of any different meaning attached by the other, and the other had reason to know the meaning attached by the first party. ${ }^{33}$

Principle I is based in large part on fault. If $A$ and $B$ engage in the formation of a contract, $A$ is negligent if she uses an expression that she should realize would lead a reasonable person in $B$ 's position to understand that $A$ attaches a given meaning, $x$, to the expression, when in fact $A$ attaches meaning $y$. If $B$ attaches meaning $x$, and as a result suffers wasted reliance or the defeat of a legitimate expectation when $A$ insists on meaning $y, A$ should be liable to $B$.

Principle II. If contracting parties subjectively attached different meanings to an expression and the two meanings were equally reasonable, neither meaning prevails.

Principle II is associated with Raffles $v$. Wichelhaus (the Peerless case) ${ }^{34}$ In Peerless, the seller agreed to sell the buyer 125 bales of Surat cotton to arrive at Liverpool "ex [ship] 'Peerless' from Bombay.",35 There were, however, two ships named Peerless that sailed from Bombay: one sailed in October, and one in December. The seller meant the December Peerless and accordingly shipped Surat cotton to the buyer on that ship. The buyer meant the October Peerless and refused to accept the cotton shipped on the December Peerless. ${ }^{36}$ The seller sued for breach of contract. The court held for the buyer on the ground that there was no "consensus ad idem [meeting of the minds]," so that no contract was formed. ${ }^{37}$ Principle II is adopted in the Second Restatement section 20(1):

There is no manifestation of mutual assent to an exchange if the parties attach materially different meanings to their manifestations and

(a) neither party knows or has reason to know the meaning attached by the other; or

(b) each party knows or each party has reason to know the meaning attached by the other. ${ }^{38}$

Principle II applies only if both parties are either fault free or equally at fault. In Peerless itself, it is likely that both parties were equally at fault.

33. Restatement (SECOND) OF Contracts § 201(2)(b) (1981).

34. See 2 H \& C 906, 159 Eng. Rep. 375 (Ex. 1864).

35. Id. at 375 .

36. The facts are as stated in the buyer's answer, to which the seller demurred. Id.

37. Id. at 376.

38. Restatement (SECOND) OF CONTRACts $§ 20(1)$. 
A.W. Brian Simpson found that at the time of the case, ships commonly shared names, and there were reports of at least eleven ships called Peerless that were sailing the seas. ${ }^{39}$ Ships bearing the same name could be differentiated by using their unique registration numbers or, much more commonly, by the names of their captains. ${ }^{40}$ On these facts, the buyer and the seller in Peerless were equally careless in assuming that the term Peerless was unambiguous.

Principle III. If contracting parties subjectively attached the same meaning to an expression, that meaning prevails even though it is unreasonable.

Where both parties negligently attached the same (unreasonable) meaning to an expression, both parties are at fault, but the fault has caused no injury. Rather, a party would be morally at fault to later claim a meaning that she herself did not attacn to the expression. Principle III is adopted in section 201(1) of the Second Restatement. That section provides that " $[w]$ here the parties have attached the same meaning to a promise or agreement or a term thereof, it is interpreted in accordance with that meaning., ${ }^{, 41}$

Principle $I V$. If contracting parties, $A$ and $B$, attached different meanings, $m$ and $n$, to an expression, and $A$ knew that $B$ attached meaning $n$, while $B$ did not know that $A$ attached meaning $m$, meaning $n$ prevails even if it is less reasonable than meaning $m$.

Principle IV is adopted in section 201(2)(a) of the Second Restatement:

Where the parties have attached different meanings to a promise or agreement or a term thereof, it is interpreted in accordance with the meaning attached by one of them if at the time the agreement was made ... that party did not know of any different meaning attached by the other, and the other knew the meaning attached by the first party ....

Although Principle IV allows a negligently adopted meaning to prevail, it is supported by a fault analysis. $B$ may have been negligent in attaching meaning $n$ to the expression, but $A$ was at greater fault in allowing $B$ to proceed on the basis of the interpretation that $A$ knew $B$ unreasonably, but actually, held. $A$ 's greater fault outweighs $B$ 's negligence.

In sum, when parties assign different meanings to contractual expressions, blameworthiness-in the form of either morally wrongful behavior or negligence (itself a special kind of moral fault) - plays a key role in determining which meaning prevails.

39. A.W. Brian Simpson, Contracts for Cotton to Arrive: The Case of the Two Ships Peerless, 1 I Cardozo L. Rev. 287, 295 (1989).

40. Id.

41. Restatement (SeCOND) of Contracts § 201(1).

42. Id. $\S 201(2)$. 


\section{MistaKe}

Mistake, like interpretation, is an area of contract law in which both negligence and strong moral fault are salient. ${ }^{43}$ Traditionally, contract law has recognized several categories of mistake, one of which is known as unilateral mistake. The term unilateral mistake normally refers to transient, mechanical errors. A common type of mistake in everyday life consists of physical blunders, like spilling coffee. This type of mistake, although manifested externally, normally results from an error in the mechanics of an actor's mental machinery, such as a lapse of concentration, a spatial or physical misconception, or a slip in hand-eye coordination. A counterpart of such physical blunders consists of intellectual blunders that result from comparable errors. For example, as a result of an error in the mechanics of an actor's mental machinery, the actor may write " 65 " when she intends to write " 56 ," or may make an error in addition.

Characterizing these kinds of blunders as mistakes assumes that for the actor in question the blunder is transient. If an actor spilled every cup of coffee he handled, we would not characterize his spills as mistakes. Instead we would say that he had some type of disability. The same is true if an actor wrote all numbers backward or was unable to add correctly. I will call mistakes of this kind-that is, blunders that result from transient errors in the actor's mental machinery-mechanical errors. Among the most common types of mechanical errors are mistaken computations, mistaken payments, misidentifications of property that is to be bought and sold, auditory or visual misperceptions, and misunderstandings of specifications, formulas, or plans. Mechanical errors resemble the kind of mistakes sometimes made in the transcription of DNA. Almost invariably, that transcription is correct. But every once in a while, it goes awry.

\section{A. The Paradigm Case: The Nonmistaken Party Is Aware of the Mistaken Party's Mechanical Error}

I begin with the paradigm case, in which the nonmistaken party, $B$, is aware of the mechanical error that was made by the mistaken party, $A$. In that case, the mistaken party should have no contractual liability. It is true that in the event of a mechanical error, normally the mistaken party is at fault, because she did not exercise due care. In the paradigm case, however, $B$ would be more strongly at fault if he tried to take advantage of this kind of error. Of course, $B$ might have formed an expectation that by concluding a contract he could benefit from $A$ 's mistake. As a matter of morality, however, if that was $B$ 's intention he would be viewed as improperly taking advantage of $A$. His expectation would be unjustified, like the expectation of a person who finds lost property and knows who the owner is, but thinks that he is entitled to benefit from the owner's carelessness-"Finders

43. Part IV draws on arguments I previously made in Melvin A. Eisenberg, Mistake in Contract Law, 91 CAL. L. REv. 1573 (2003). 
Keepers." Judge Posner's analysis of a case involving postcontract conduct is applicable here by analogy:

[I]t is one thing to say that you can exploit your superior knowledge of the market-for if you cannot, you will not be able to recoup the investment you made in obtaining that knowledge .... It is another thing to say that you can take deliberate advantage of an oversight by your contract partner concerning his rights under the contract. Such taking advantage is not the exploitation of superior knowledge or the avoidance of unbargained-for expense; it is sharp dealing. Like theft, it has no social product, and also like theft it induces costly defensive expenditures, in the form of overelaborate disclaimers or investigations into the trustworthiness of a prospective contract partner, just as the prospect of theft induces expenditures on locks. ${ }^{44}$

This position is adopted in section 153 of the Second Restatement and in many cases. An offeree cannot snap up an offer that is too good to be true. ${ }^{45}$

\section{B. The Nonmistaken Party Had Reason to Know of the Mistaken Party's Mechanical Error}

Suppose that the nonmistaken party is not proven to have been aware of a mechanical error, but had reason to know of the error. Here the fault analysis is not as clear as it is in the paradigm case. In the paradigm case, $B$ knowingly attempts to take advantage of $A$ 's mechanical error; in the reason-to-know case, he does not. Nevertheless, although $A$ is at fault for making the mistake, $B$ is at fault for his negligence in failing to realize that a mistake was made when a reasonable person would have done so. Furthermore, administrability considerations strongly favor relief in the reason-toknow case. Only the nonmistaken party knows with certainty whether he was actually aware of a mechanical error. Proving actual (subjective) awareness by the nonmistaken party therefore will usually be too difficult a burden for the mistaken party to shoulder. Where the nonmistaken party had reason to know of a mechanical error, he probably did know. Accordingly, the reason-to-know case should be treated like the paradigm case to protect the integrity of the rule that governs that case.

\section{Cases in Which the Nonmistaken Party Neither Knew nor Had Reason to Know of the Mechanical Error}

Suppose the nonmistaken party, $B$, did not know or have reason to know of the mechanical error made by the mistaken party, $A$. This kind of case presents two issues. First, should $A$ be liable for $B$ 's reliance damages? Second, should $A$ be liable for $B$ 's expectation damages?

44. Mkt. St. Assocs. Ltd. P'ship v. Frey, 941 F.2d 588, 594 (7th Cir. 1991).

45. See, e.g., United States v. Braunstein, 75 F. Supp. 137, 139 (S.D.N.Y. 1947); Speckel v. Perkins, 364 N.W.2d 890 (Minn. Ct. App. 1985); see also 1 Samuel Williston \& George J. Thompson, A TREATISE ON THE LAW of ConTracts § 94, at 297 (rev. ed. 1936). 
In the paradigm case, where $B$ is aware of $A$ 's mechanical error, $B$ 's reliance should make no difference. If $B$ is aware that $A$ made a mechanical error, $B$ 's reliance is unjustified. However, if $B$ relies when he is neither aware nor has reason to be aware that $A$ made a mechanical error, then $B$ 's reliance is justified; $A$ 's fault has caused a loss to $B$; and at a minimum, $A$ should compensate $B$ for that loss by paying reliance damages.

Whether the mistaken party should be liable for expectation damages in such a case is a more difficult issue. Older contract law took the position that a mechanical error (or, in the traditional nomenclature, a unilateral mistake) was not a defense against expectation damages unless the nonmistaken party either knew or had reason to know of the mistake. ${ }^{46}$ In contrast, modern contract law takes the position that a mechanical error is a defense to expectation damages, at least where the result of enforcing the contract through expectation damages would be "unconscionable.",77

It is true that where $B$ neither was aware nor should have been aware of the mistake, $A$ is at fault, and $B$ has formed a justified expectation as a result of $A$ 's fault. That, however, is not dispositive. For example, if $A$ negligently makes a mistaken payment to $B$, and $B$ neither knows nor has reason to know that a payment is mistaken, then as a result of $A$ 's fault $B$ may form a justified expectation that the payment is his to keep. However, that expectation is not protected by the law. ${ }^{48}$ Similarly, where $A$ has negligently lost personal property and $B$, who finds the property, reasonably believes that the property was abandoned, $B$ forms a justified expectation that the property is now his. Again, however, that expectation is not protected.

As in those cases, the fact that the nonmistaken party in a mechanicalerror case formed a justified expectation does not mean that he acts fairly in insisting on full enforcement of the contract after he understands that his counterparty had made such an error. On the contrary, just as a payee is morally obliged to return a mistaken payment once he learns the payment was mistaken, and a finder is morally obliged to return lost property once he knows that it was lost rather than abandoned, so too a party to a contract that is based on a mechanical error would be morally overreaching if he insisted on full enforcement after he learned of the error. This principle is embodied in section 153 of the Second Restatement and the modern cases. ${ }^{49}$

Normally, the principle of unconscionability is applied ex ante, at the time a bargain is made, to determine whether the bargaining process, the bargain, or both conformed to moral standards. In the context of mechanical errors, however, the concept of unconscionability refers to cases where it is

46. Anthony T. Kronman, Mistake, Disclosure, Information, and the Law of Contracts, $7 \mathrm{~J}$. Legal STud. 1, 5 (1978).

47. See, e.g., RESTATEMENT (SECOND) OF CONTRACTS § 153(a) (1981).

48. See, e.g., Glover v. Metro. Life Ins. Co., 664 F.2d 1101, 1105 (8th Cir. 1981) ("In all the circumstances, it would be unjust, in our view, for [an unknowing mistaken payee] to keep the money. This result disappoints an expectation on her part that she had every reason to believe, at one time, to be legitimate, but to decide otherwise would be intolerably unfair to [the mistaken payor].").

49. See Donovan v. RRL Corp., 27 P.3d 702 (Cal. 2001). 
morally improper to seek full enforcement of a promise that was based on such an error. ${ }^{50}$ In these cases, the nonmistaken party will be restored to his precontract wealth by an award of reliance damages. A fair-minded person who has been made whole in this way would not try to take advantage of a mechanical error by inflicting a further loss on the mistaken party so as to make a gain that is not earned by knowledge, skill, or diligence. As in other areas of contract law, therefore, fault should and does play a significant role in the outcomes in at least this category of mistake cases.

\section{NONPERFORMANCE}

The subjects discussed in Parts I through IV do not exhaust the areas of contract law in which fault plays a significant role. Other such areas are-to name just a few-fraud, duress, undue influence, and the duty to perform in good faith. Of course, some rules of contract law turn exclusively on policy and empirical considerations. Examples are the mailbox rule, the parol evidence rule, and the Statute of Frauds. In still other areas, such as disclosure, fault considerations are largely although not entirely trumped by policy considerations. However, the existence of some contract-law rules that are not driven by fault does not mean that contract law is not fault based, any more than the existence of some strict-liability rules in tort law means that tort law is not fault based.

Why, then, do various authorities conclude that contract law is based on strict liability, not fault? Perhaps these authorities have in mind not contract law but rather one area of contract law: liability for nonperformance of a bargain promise. The idea that liability in this area is strict, not fault based, has a superficial appeal. In torts, the plaintiff normally prevails only if the defendant acted wrongfully by intentionally inflicting an injury or failing to exercise due care. In contracts, the plaintiff normally prevails if a contract was formed and the defendant did not perform her part of the contract. It is therefore tempting to reach the conclusion that liability in contract for nonperformance is strict, and is based on policy reasons rather than moral reasons.

However, this is an oversimplified view of the morality of promising and the basis of liability for nonperformance. In the area of nonperformance, law and morality, although not identical, tend to converge rather than diverge. Morally, a promise is a commitment to take a certain action, such as the achievement of a given result, even if at the time the action is to be taken, the promisor would prefer not to fulfill her promise, all things considered. The mere fact that a promisor has not intentionally or negligently failed to perform is not a moral excuse for nonperformance, because the moral commitment of a promisor extends further. Neither is it a moral excuse for nonperformance that when the time comes to perform the promise, it would

50. McMaster Univ. v. Wilchar Constr. Ltd., [1971] 3 O.R. 801, 811 (Can.); see also Stepps Invs. Ltd. v. Sec. Capital Corp., [1976] 14 O.R.2d 259, 27 I (Can.). 
hurt to do so. To believe that any of these reasons are moral excuses for not performing a promise would be to misunderstand the nature of promising.

On the other hand, nonperformance of a promise is morally permissible if there is a moral excuse for not performing. One such excuse is that performance would not only hurt, but hurt very badly. As Thomas Scanlon says,

Saying "I promise to ..." normally binds one to do the thing promised, but it does not bind unconditionally or absolutely. ... It does not bind absolutely because, while a promise binds one against reconsidering one's intention simply on grounds of one's own convenience, it does not bind one to do the thing promised whatever the cost to oneself and others. ${ }^{\text {s. }}$

Similarly, the fact that performance of a promise hurts very badly may be a legal excuse under the doctrine of impracticability, which rests in significant part on whether a promised performance has become much more costly than was contemplated at the time of contract formation.

More generally, it is inaccurate to say that liability for nonperformance is established by showing contract formation and nonperformance. To these elements must be added the lack of an excuse for nonperformance. The legal structure of liability for nonperformance builds on the moral structure of promising, and neither the moral nor the legal obligation is an example of strict liability. If I promise you that I will meet you for lunch and I don't show up, I am at fault, and "strict liability" doesn't enter the picture. The same is true if I promise to sell you one hundred widgets and don't deliver. Of course, in the lunch hypothetical, if I have a good excuse for not showing up—for example, if I suddenly fell ill—I wouldn't be at fault. Similarly, if I have a good excuse for not delivering the widgets, such as a blockade or a fire, I won't be liable. It's true that what constitutes a good excuse in the widgets hypothetical may be different from what constitutes a good excuse in the lunch hypothetical, but that is largely because of the different context and subject matter, not because one nonperformance is judged under a fault standard and the other is judged under a strict liability standard.

The fault basis of liability for contractual nonperformance is well summarized by Barry Nicholas:

Fault is ... absent from the conventional common law conception of liability for breach of contract only because it is in substance incorporated in the meaning of 'contract'. So in a formulation such as that in Restatement $2 \mathrm{~d}$ Contracts, $\S 235(2)$ : 'When performance of a duty under a contract is due any non-performance is a breach', the part played by fault is incorporated in the duty.

51. Thomas M. Scanlon, Promises and Practices, 19 PhiL. \& Pub. AfF. 199, 214 (1990).

52. Barry Nicholas, Fault and Breach of Contract, in Good Faith and Fault IN CONTRACT Law 337, 345 (Jack Beatson \& Daniel Friedmann eds., 1995). 


\section{CONCLUSION}

It is not surprising that fault plays a significant role in contract law. On the contrary, it would be surprising if it didn't. For one thing, moral norms are basic building blocks in all fields of law. For another, the efficiency of the contracting system would be materially impaired if fault did not play a significant role. The efficiency of that system rests on a tripod whose legs are legal remedies, reputational effects, and the internalization of social norms - in particular, the moral norm of promise keeping. These three legs are mutually supportive. Legal rules rest in significant part on social norms, reputational effects rest in significant part on social norms, and social norms are reinforced by legal rules and reputational effects.

All three of these legs are necessary to ensure the reliability, and therefore the efficiency, of the contracting system. Legal rules are not alone sufficient, because dispute settlement under law is expensive and chancy. The moral norm of promise keeping is not alone sufficient, because not all actors fully internalize moral norms. And reputational effects are not alone sufficient, because reliable information concerning a promisor's history of breach is often hard to come by and often disregarded even when known.

Because all three legs are necessary to support the efficiency of the contracting system, anything that weakens one leg seriously threatens the efficiency of that system. Giving effect to a theory that fault does not play an important role in contract law would remove the moral force of promising in a bargain context and would thereby decrease the efficiency of the contracting system in three ways. First, it would lead contracting parties to make greater use of costly noncontractual measures, such as security deposits, to ensure performance. Second, it would diminish the force of reputational constraints, because such constraints rest in significant part on moral norms. Finally, and most importantly, it would increase the need to resort to litigation, which is very expensive, as opposed to achieving performance of contracts through the internalization of the moral norm of promise keeping, which is very inexpensive. 